\title{
Türkiye Florasından Toplanmış Festuca L. Genotiplerinde Morfolojik-Agronomik Varyasyon
}

\author{
Medine ÇOPUR DOĞRUSÖZ*1 ${ }^{*}$, Ahmet TAMKOÇ ${ }^{2}$ \\ Geliş / Received: 28/08/2019 \\ Revize / Revised: 23/10/2019 \\ Kabul / Accepted: 23/10/2019
}

$\ddot{\mathbf{O Z Z}}$

Bu çalışma, Türkiye florasından toplanmış beş Festuca türüne ait toplam 497 genotipte morfolojik ve agronomik özelliklerin varyasyonu değerlendirilmiştir. Çalışma kapsamında toplanan tohumlar ve köklü bitkiler, serada saksılara ekilmiş ve daha sonra fidanlar Konya'da 2015 yılında $0.5 \mathrm{~m}$ x $0.5 \mathrm{~m}$ dikim aralıkları ile araziye aktarılmıştır. Festuca taksonundan 2016 yılında alınan morfo-agronomik gözlemler çim kalitesi, renk, yaprak dokusu, yoğunluk, sonbahar büyüme şekli, bitki boyu, yaprak genişliği, yaprak boyu, salkım boyu, son boğum uzunluğu, bitki başına tohum verimi ve 1000 tane ağırlı̆̆ıdır. Bazı görsel özelliklerin (çim kalitesi, renk, yaprak dokusu) değerlendirilmesinde 1-9 skalası kullanılmıştır. Sonuçlara göre, $F$. arundinacea en yüksek çim kalitesine (6.90), renk (5.75), yaprak dokusu (3.03) ve yaprak genişliğine $(2.79 \mathrm{~mm})$ sahip olmuştur. En ince yaprak dokusu $F$. ovina' da tespit edilirken, en kısa bitki boyu $F$. valesiaca' da ve $F$. en düşük tohum verimi pratensis'te saptanmıştır. İncelenen özellikle göre Festuca L. türlerinde yüksek CV değerlerinin oluşması tür içi ve türler arası çeşitliliğin yüksek olduğunu ortaya koymaktadır. Bu durum Festuca cinsinde ki seleksiyon ve ıslah çalışmalarında büyük avantaj sağlayabilir.

Anahtar Kelimeler- Festuca, Varyasyon, Bitki Boyu, Çim Kalitesi, Tohum Verimi.

\footnotetext{
1*Sorumlu yazar iletişim: medine.copur@bozok.edu.tr (https://orcid.org/0000-002-9159-1699)

Tarla Bitkileri Bölümü, Yozgat Bozok Üniversitesi, Yozgat.

2illetişim: atamkoc@selcuk.edu.tr (https://orcid.org/0000-002-8343-9101)

Tarla Bitkileri, Selçuk Üniversitesi, Konya.
} 


\title{
Morpho-Agronomic Variation in Festuca L. Genotypes from Turkey Flora
}

\begin{abstract}
In this study, a total of 497 taxon and five species of Festuca genus from Turkey flora were evaluated for morpho-agronomic variation. The collected seeds and rooted plants were sown to pots in greenhouse and then seedlings were transferred to field by $0.5 \mathrm{~m}$ x $0.5 \mathrm{~m}$ spaces in 2015 in Konya. In 2016, Morpho-agronomic observations of Festuca taxon were turf quality, color, leaf tissue, density, autumn growth type, plant height, leaf width, leaf length, cluster height, last node height, seed yield per plant and 1000 seed weight. Scales 1-9 were used to evaluate some visual characteristics (turf quality, color, leaf texture). According to the results, $F$. arundinacea had the highest turf quality (6.90), color (5.75), leaf tissue (3.03), leaf width (2.79 mm). The thinnest tissue was detected in F. ovina while the shortest plant height in $F$. valesiaca and the lowest seed yield in F. pratensis, Most of the investigated parameters showed high CV which highlighted the existence of high inspecies and inter-species variation of Festuca L. in Turkey. This case may provide a great advantage in breeding and selection studies on Festuca genus.
\end{abstract}




\section{INTRODUCTION}

The Festuca is the largest genus within the Pooideae subtribe of the Poaceae family, and contains over 400 species [1,2]. Species of Festuca vary in morphology, with cosmopolitan distribution and it is an important component of grass ecosystems of the temperate zone. Turkey is one of the richest and interesting countries in the world in respect to Festuca genus, as previously noted in other resources. Turkey has floristic attraction for Festuca with the 52 species and, this richness is creating great genetic potential for breeding [3].

Festuca L. is a widely used in temperate regions both turf and forage grass, with many known species [4]. Also, Festuca species are important for erosion control in mountainous areas as well as forage grasses for animals [5]. In this respect, $F$. arundinacea (tall fescue), is one of the most agriculturally important species of Festuca genus was used in land reclamation projects during the "Dust Bowl" period of the 1930s in the United States [6]. Tall fescue with broad-leaved is used widely for green forage as well as conservation purposes and turf [7]. It has high yield stability and adaptation to different environments [8]. Meadow fescue (F. pratensis) has many positive traits such us tolerance to abiotic and biotic stresses, good persistence and adaptation to grazing and frequent cutting and high nutritive quality. Sheep fescue (F. ovina), another important species of Festuca L., its early grow and vigorous root system make it competitiveness with other grasses and, it is fairly resistant to drought and trampling by animals $[9,10]$. Sheep fescue is also tolerant to frequent grazing because of their growth characteristics and broad temporal adaptation on rangelands. There have been many studies on the morphological variation in the diverse species of the Festuca, especially on the leaves due to high variation from fine to broad [11]. Same authors studied on F. pratensis, F. arundinacea, F. rubra and F. ovina collected from various locations of Turkey found that thousand seed weight were 2, 2, 1.2 and $0.7 \mathrm{~g}$, and plant height between 40-100, 120-150, 40-90 and 10-60 cm respectively in the studied species. [12] Previously, 100-160 cm plant height, 18-24 cm cluster height, 2.2-2.49 g thousand seed weight were measured on the $F$. arundinacea [13] In $F$. ovina subspecies, $20-50 \mathrm{~cm}$ plant height, 0.8-1.0 g thousand seed weight were noted, [14] It was reported that turf grass traits of $F$. arundinacea were 4.11 to 6.97 for leaf tissue, 6.47 to 6.90 for color, 6.94 to 8.36 for turf quality and 7.93 to 8.98 for thinning (1-9 scale).

This natural species or genotypes are inherently diverse because of adaptation to many climates and locations over many years. Many of new varieties were developed by the selection of promising genotypes from natural fields. In this case, understanding morphologic diversity of certain species is not only useful in addressing the evolutionary process, but also a prerequisite for efficient use of genetic resources in breeding programs. Also, interest in the genetic structure of natural populations of grass species has been increased in the last few years due to the necessity of broadening the knowledge of genetic variations in Turkey.

Present study was performed to identify some morpho-agronomic characteristics in 5 Festuca species collected from Turkey, especially uses in the evaluation of turf grass.

\section{MATERIAL AND METHOD}

In the present research, 5 Festuca species consisted from the project of coded with "TUBITAK 1130919 " in 2014 were used. A total of 497 Festuca L. genotype were formed by 130 of $F$. arundinacea Schreb., 217 of F. ovina L., 27 of $F$. pinifolia (Hack. ex Boiss) Bornm., 46 of $F$. pratensis Huds., and 77 of $F$. valesiaca Schleich. ex Gaudin. Their rooted plants and seeds were collected from 13 Cities (Ankara, Cankiri, Corum, Yozgat, Eskisehir, Afyon, Konya, Aksaray, Nigde, Karaman, Kırsehir, Kayseri, Kirikkale, Sivas, Mersin and Antalya) of Turkey.

The collected seeds and the rooted plants were sown to pots in greenhouse and then they were transferred to field by $0.5 \mathrm{~m} \times 0.5 \mathrm{~m}$ spaces in 2015 in Konya. The soil at the experimental site taken $30 \mathrm{~cm}$ depth is classified as clay-loam with $\mathrm{pH}$ : 7.34 , low organic matter $(1.82 \%)$, medium $\mathrm{P}_{2} \mathrm{O}_{5}\left(6.07 \mathrm{~kg}\right.$ da-1) and high $\mathrm{K}_{2} \mathrm{O}$ (201.77 kg da-1) content. Annual rainfall, average temperature and moisture are $330 \mathrm{~mm}, 11.8{ }^{\circ} \mathrm{C}$ and $54.8 \%$, respectively in the experimental site in 2016. In the trial regular turf maintenance techniques were carried out such as irrigation, fertilization, weed control and cutting. The data for investigated characteristics was collected in 2016 during the period from flowering to seed maturity. These characteristics are turf quality (1-9 scale), color, leaf tissue (1-9 scale), density (1-9 scale), autumn growth type (1-9 scale), plan height (cm), leaf width $(\mathrm{mm})$, leaf length $(\mathrm{cm})$, cluster height $(\mathrm{cm})$, last node height $(\mathrm{cm})$, seed yield per plant and 1000 seed weight. In 
scale $1-9,1$ refers to lowest or bad while 9 to the best or the highest value $[15,16]$. The data was evaluated separately for each species and statistically analyzed in SPSS version 20.0.

\section{RESULTS AND DISCUSSION}

Mean values and some statistical data of detected morpho-agronomic characteristics in the genotypes of F. arundinacea Schreb., F. ovina L., F. pinifolia (Hack. ex Boiss) Bornm., F. pratensis Huds. and F. valesiaca Schleich. ex Gaudin were given inTable 1,2,3,4 and 5. Average of the turf quality was similar as 6-7 (well) almost in all species. But, the highest turf quality was determined in $F$. arundinacea (6.90) genotypes and the lowest turf quality was appointed in $F$. pratensis (6.76) genotypes. Although the coefficient of variation was similar all species, the highest CV content was examined in F. ovina L. (12.66\%) genotypes. The color property determined by 1-9 scale, $F$. arundinacea genotypes have been darker color than the other species. The color property is fairly importance in breeding trials because the color may vary depending on the turf grass (Table 1).

Table 1. Mean, minimum, maximum values, standard deviation (Sd) and coefficient of variation (CV) for the turf quality and color in examined Festuca L. species

\begin{tabular}{lcccccc|ccccc}
\hline \multirow{2}{*}{ Species } & $\mathbf{n}$ & \multicolumn{4}{c}{ Turf quality (1-9) } & \multicolumn{4}{c}{ Color (1-9) } \\
\cline { 3 - 11 } & & Mean & Min. & Max. & Sd. & CV(\%) & Mean & Min. & Max. & Sd. & CV(\%) \\
\hline F. arundinacea & 130 & 6.90 & 5.00 & 8.00 & 0.83 & 12.09 & 5.75 & 1.00 & 9.00 & 1.29 & 22.50 \\
F. ovina & 217 & 6.82 & 4.00 & 9.00 & 0.86 & 12.66 & 5.44 & 2.00 & 8.00 & 1.34 & 24.69 \\
F. pinifolia & 27 & 6.78 & 6.00 & 8.00 & 0.75 & 11.08 & 5.07 & 3.00 & 8.00 & 1.44 & 28.36 \\
F. pratensis & 46 & 6.76 & 5.00 & 8.00 & 0.85 & 12.54 & 5.39 & 3.00 & 8.00 & 1.29 & 23.94 \\
F. valesiaca & 77 & 6.81 & 5.00 & 9.00 & 0.83 & 12.16 & 5.22 & 3.00 & 8.00 & 1.22 & 23.30 \\
\hline
\end{tabular}

Table 2. Mean, minimum, maximum values, standard deviation (Sd) and coefficient of variation (CV) for the leaf tissue and density in examined Festuca L. species

\begin{tabular}{|c|c|c|c|c|c|c|c|c|c|c|c|}
\hline \multirow{2}{*}{ Species } & \multirow{2}{*}{$\mathbf{n}$} & \multicolumn{5}{|c|}{ Leaf tissue (1-9) } & \multicolumn{5}{|c|}{ Density (1-9) } \\
\hline & & Mean & Min. & Max. & Sd. & CV $(\%)$ & Mean & Min. & Max. & Sd. & $\mathrm{CV}(\%)$ \\
\hline F. arundinacea & 130 & 3.03 & 1.00 & 8.00 & 1.13 & 37.41 & 5.89 & 1.00 & 8.00 & 1.53 & 25.90 \\
\hline F. ovina & 217 & 2.46 & 1.00 & 6.00 & 1.17 & 47.72 & 5.62 & 1.00 & 8.00 & 1.54 & 27.33 \\
\hline F. pinifolia & 27 & 2.48 & 1.00 & 5.00 & 1.28 & 51.67 & 5.44 & 2.00 & 8.00 & 1.72 & 31.54 \\
\hline F. pratensis & 46 & 2.93 & 1.00 & 6.00 & 1.22 & 41.52 & 6.02 & 3.00 & 8.00 & 1.44 & 23.87 \\
\hline F. valesiaca & 77 & 2.85 & 1.00 & 6.00 & 1.25 & 44.03 & 5.41 & 3.00 & 8.00 & 1.42 & 26.29 \\
\hline
\end{tabular}

Leaf tissue and density are the characters related to the general appearance of plant and leaves. Leaf tissue of the species were ranged between $2.46(F$. ovina) and 3.03 ( $F$. arundinacea) with a medium coefficient of variation. Average leaf tissue of $F$. arundinacea was thicker than other species while $F$. ovina was the thinnest. Average density of $F$. pratensis and $F$. arundinacea were determined by 6.02 and 5.89 , respectively. It is also noteworthy to mention that these species may use as forage or in pastures. The lowest density was determined in $F$. valesiaca genotypes as a mean of 5.41. However, regarding to leaf tissue and density, the highest variation was determined in $F$. pinifolia $(51.67,31.54 \%)$ and $F$. ovina $(47.72,27.33 \%)$ genotypes. 
Table 3. Mean, minimum, maximum values, standard deviation (Sd) and coefficient of variation $(\mathrm{CV})$ for the plant height and leaf width in examined Festuca L. species

\begin{tabular}{|c|c|c|c|c|c|c|c|c|c|c|c|}
\hline \multirow{2}{*}{ Species } & \multirow{2}{*}{$\mathbf{n}$} & \multicolumn{5}{|c|}{ Plant height $(\mathrm{cm})$} & \multicolumn{5}{|c|}{ Leaf width (mm) } \\
\hline & & Mean & Min. & Max. & Sd. & $\mathrm{CV}(\%)$ & Mean & Min. & Max. & Sd. & $\mathrm{CV}(\%)$ \\
\hline F. arundinacea & 130 & 38.81 & 15.00 & 95.00 & 13.10 & 36.59 & 2.79 & 0.50 & 10.00 & 1.57 & 56.42 \\
\hline F. ovina & 217 & 32.82 & 5.00 & 79.00 & 14.29 & 43.54 & 1.80 & 0.50 & 3.00 & 1.07 & 29.49 \\
\hline F. pinifolia & 27 & 35.00 & 8.00 & 94.00 & 19.03 & 54.38 & 2.25 & 0.50 & 4.00 & 1.02 & 45.36 \\
\hline$F$. pratensis & 46 & 38.78 & 11.00 & 90.00 & 12.57 & 32.42 & 2.48 & 0.50 & 6.00 & 1.11 & 44.91 \\
\hline F. valesiaca & 77 & 32.79 & 7.00 & 73.00 & 12.69 & 38.70 & 2.24 & 0.50 & 5.00 & 1.12 & 50.21 \\
\hline
\end{tabular}

In the green areas, the thin-leafed and the short plants are preferred to reduce maintenance costs. In this context, mean plant height varied from 32.79 (F. valesiaca) to $38.81 \mathrm{~cm}(F$. arundinacea) in fescue species. Furthermore, plant height up to $95 \mathrm{~cm}$ was recorded in $F$. arundinacea while it was as low as $5.00 \mathrm{~cm}$ in $F$. ovina genotypes. In terms of averages of leaf width, the lowest value was in $F$. ovina $(1.80 \mathrm{~mm})$ with minimum $\mathrm{CV}$ (29.49\%), and the highest value was in $F$. arundinacea $(2.79 \mathrm{~mm})$ with maximum CV $(56.42 \%)$.

Table 4. Mean, minimum, maximum values, standard deviation (Sd) and coefficient of variation (CV) for the leaf length and cluster height in examined Festuca L. species

\begin{tabular}{lccccccccccc}
\hline \multirow{2}{*}{ Species } & \multirow{n}{*}{$\mathbf{n}$} & \multicolumn{4}{c}{ Leaf length $(\mathbf{c m})$} & \multicolumn{4}{c}{ Cluster height (cm) } \\
\cline { 3 - 12 } & & Mean & Min. & Max. & Sd. & CV(\%) & Mean & Min. & Max. & Sd. & CV(\%) \\
\hline F. arundinacea & 130 & 8.52 & 5.00 & 27.00 & 4.09 & 48.00 & 5.99 & 2.00 & 15.00 & 1.98 & 33.08 \\
F. ovina & 217 & 7.22 & 2.00 & 21.00 & 3.31 & 45.85 & 6.40 & 2.00 & 18.00 & 2.56 & 39.96 \\
F. pinifolia & 27 & 6.77 & 2.00 & 14.00 & 2.67 & 39.44 & 6.00 & 2.00 & 17.00 & 3.71 & 61.91 \\
F. pratensis & 46 & 7.33 & 3.00 & 18.00 & 2.53 & 34.52 & 5.94 & 3.00 & 13.00 & 2.34 & 39.39 \\
F. valesiaca & 77 & 6.92 & 2.00 & 15.00 & 3.43 & 49.59 & 6.42 & 3.00 & 14.00 & 2.77 & 43.14 \\
\hline
\end{tabular}

Among these five fescue species, mean leaf length was varied between 6.77 ( $F$. pinifolia) and $8.52 \mathrm{~cm}$ (F. arundinacea) and cluster height varied from 5.94 (F. pratensis) to $6.42 \mathrm{~cm}$ (F. valesiaca) (Table 4). All species had high coefficient variation for these characters, especially $F$. valesiaca $(49.59 \%)$ and $F$. pinifolia $(61.91 \%)$.

F. arundinacea has shown maximum value of plant height, leaf width and length as $38.81 \mathrm{~cm}, 2.79 \mathrm{~mm}$ and $8.52 \mathrm{~cm}$, respectively. These results show that $F$. pratensis and $F$. arundinacea can be suitable as forage, while $F$. valesiaca, $F$. ovina and $F$. pinifolia as turf grass. Previously, this conclusion supported by [10]. However, each species should be evaluated separately due to high intra-species variation. In other words, each species can include genotypes suitable for use as both forage and turf grass.

Table 5. Mean, minimum, maximum values, standard deviation (Sd) and coefficient of variation (CV) for the last node height and seed yield per plant in examined Festuca L. species

\begin{tabular}{|c|c|c|c|c|c|c|c|c|c|c|c|}
\hline \multirow{2}{*}{ Species } & \multirow{2}{*}{$\mathbf{n}$} & \multicolumn{5}{|c|}{ Last node height $(\mathrm{cm})$} & \multicolumn{5}{|c|}{ Seed yield per plant (g) } \\
\hline & & Mean & Min. & Max. & Sd. & $\mathrm{CV}(\%)$ & Mean & Min. & Max. & Sd. & $\mathrm{CV}(\%)$ \\
\hline F. arundinacea & 130 & 19.54 & 6.00 & 39.00 & 6.32 & 34.11 & 1.85 & 0.95 & 3.40 & 0.67 & 36.47 \\
\hline F. ovina & 217 & 19.44 & 7.00 & 63.00 & 9.02 & 46.39 & 1.45 & 0.25 & 6.83 & 1.36 & 93.79 \\
\hline F. pinifolia & 27 & 18.10 & 7.00 & 45.00 & 8.73 & 48.24 & 1.22 & 0.29 & 2.60 & 0.89 & 72.61 \\
\hline F. pratensis & 46 & 19.53 & 9.00 & 33.00 & 5.94 & 30.44 & 1.00 & 0.25 & 2.35 & 0.68 & 67.87 \\
\hline F. valesiaca & 77 & 17.55 & 8.00 & 37.00 & 6.06 & 34.51 & 1.74 & 0.35 & 4.20 & 0.96 & 54.97 \\
\hline
\end{tabular}


Last node height averaged between 17.55 (F. valesiaca) and $19.54 \mathrm{~cm}(F$. arundinacea $)$ and seed yield per plant varied from 1.00 ( $F$. pratensis) to $1.85 \mathrm{~g}(F$. arundinacea) (Table 5$)$. Mean 1000 seed weight ranged between 0.76 ( F . pinifolia) and 1.64g ( F. arundinacea) in Festuca L. Similarly the range of autumn growth type was between 4.87 ( $F$. pratensis) and 5.60 ( $F$. arundinacea) (Table 6$)$. And, the maximum value of seed yield per plant was detected in $F$. ovina while the maximum 1000 seed weight was in $F$. arundinacea. However, mean seed yield per plant and 1000 seed weight were the highest in F. arundinacea with low CV (36.47 and 35.52\%, respectively). The highest variation among the investigated characters was observed in seed yield per plant, especially in F. ovina with $93.79 \%$ CV (Table 5).

Table 6. Mean, minimum, maximum values, standard deviation (Sd) and coefficient of variation (CV) for the 1000 seed weight and autumn growth type in examined Festuca L. species

\begin{tabular}{|c|c|c|c|c|c|c|c|c|c|c|c|}
\hline \multirow{2}{*}{ Species } & \multirow{2}{*}{$\mathbf{n}$} & \multicolumn{5}{|c|}{1000 seed weight $(\mathrm{g})$} & \multicolumn{5}{|c|}{ Autumn growth type (1-9) } \\
\hline & & Mean & Min. & Max. & Sd. & $\operatorname{CV}(\%)$ & Mean & Min. & Max. & Sd. & CV(\%) \\
\hline F. arundinacea & 130 & 1.64 & 0.82 & 3.24 & 0.58 & 35.52 & 5.60 & 3.00 & 9.00 & 1.72 & 30.69 \\
\hline F. ovina & 217 & 1.02 & 0.05 & 2.50 & 0.46 & 44.91 & 5.03 & 1.00 & 9.00 & 1.85 & 36.74 \\
\hline F. pinifolia & 27 & 0.76 & 0.34 & 1.35 & 0.28 & 36.48 & 5.46 & 1.00 & 9.00 & 2.18 & 39.99 \\
\hline$F$. pratensis & 46 & 0.82 & 0.38 & 1.38 & 0.39 & 48.12 & 4.87 & 3.00 & 7.00 & 1.77 & 36.32 \\
\hline F. valesiaca & 77 & 0.94 & 0.49 & 2.18 & 0.39 & 41.35 & 5.21 & 3.00 & 9.00 & 1.76 & 33.83 \\
\hline
\end{tabular}

The fescue species exhibited high variation for most of the studied traits, which all had a coefficient variation of higher than $10 \%$. This variation can be attributed to the ecological and genetic factors. Also, due to outcrossing in all the species this results are expected as reported many authors $[7,9,11,12,13,14]$ who are study with grass species collected from natural land. The high variation may give an alternative to select better samples and a contribution to success in breeding.

\section{CONCLUSION}

This research, a total of 497 Festuca L. genotypes that are consisted from five different species presented quite more variations for the investigated characteristics. As a result of this study, it was highlighted the existence of variability in-species and inter-species and once again reveals the genetic diversity of Turkey in terms of Festuca L.. According to the results of the parameters examined, totally 34 Festuca L. genotypes which are $4 \mathrm{~F}$. arundinacea, $20 \mathrm{~F}$. ovina, $1 \mathrm{~F}$. pratensis, $1 \mathrm{~F}$. pinifolia and $8 \mathrm{~F}$. valesiaca were determined to be superior to use turf grass. However, owing to dominant effects of environment factors on perennial plants, it is fair that the investigated characteristics in the study should be collected again in the fallowing years to stability and reliability.

\section{ACKNOWLEDGEMENT}

This study has been designed from the Medine COPUR DOGRUSOZ doctoral thesis and, we thank TUBITAK for supports in the collection of plant materials with 1130919 project.

\section{REFERENCES}

[1] Clayton, W.D. \& Renvoize, S.A. (1986). Genera Graminum: Grasses of the world. In: Cope TA (ed) Kew Bulletin Additional Series 13, Royal Botanic Gardens, Kew, London, pp 1-389.

[2] Watson, L. \& Dallwitz, M.J. (1992). The Grass Genera of the World. CAB International, Wallingford, UK.

[3] Guner, A. (2012). Turkey List of plants, vascular plants. ANG vakfi. S 74-79.

[4] Ianniello, D. (2011). Information for Growing a nice, green Richmond lawn. http://www.omlawncare.com/careguide.html. 24 February 2011. 
[5] Namaganda, M., Lye, K.A., Friebe, B. \& Heun, M. (2006). AFLP-based differentiation of tropical African Festuca species compared to the European Festuca complex. Theor Appl Genet 113:1529- 1538.

[6] Schardl, C.L. \& Leuchtmann, L. (2005). The fungal community: its organization and role in the ecosystem. In: Dighton J, Jr JFW, Oudemans P (eds) The Epichloë endophytes of grasses and the symbiotic continuum. Third Edition. CRC Press, Boca Raton, Florida, pp 475-503

[7] Collins, M. \& Hannaway, D.B. (2003). Forage-related animal disorders. 'Forages volume I: An introduction to grassland agriculture' In: Barnes, Nelson, Collins, Moore (Eds) 6th ed. Iowa State University Press. Ames. IA.

[8] Al-Ghumaiz, N.S. (2006). Evaluation of the persistence and productivity of perennial cool season grasses and clovers grown in monoculture and binary mixtures in Michigan. Ph.D Dissertation, Michigan State University, East Lansing, MI, USA.

[9] Ruemmele, B.A., Wipff, J.K., Brilman, L. \& Hignight, K.W. (2003). Fine-leaved Festuca species, in Turfgrass Biology, Genetics, and Breeding, Casler, M.D. and Duncan, R.R. Eds., Wiley, Hoboken, NJ.

[10] Monsen, S.B., Richard, S. \& Shaw, N. (2004). Grasses chapter 18. USDA Forest Service Gen Tech Rep RMRS-GTR-136: 295-424.

[11] Ayan, I. \& Acar, Z. (2009). Fescue species (Festuca L.). Forage croprs - legumes family. Cilt III, Ministry of Agriculture and Rural Affairs, İzmir, p: 89-98.

[12] Dzyubenko, N.I. \& Dzyubenko, E.A. (2011). Crops, Festuca arundinacea Schreb. - Tall fescue. www.agroatlas.ru/en/content/cultural/Festuca_arundinacea_K/.

[13] Peeters, A. (2011). Ryegrass. www.fao.org/ag/AGP/agpc/doc/GBASE/data/pf000449.htm.

[14] Erasik, T. (2014). Investigations on the Turf Quality of Some New Tall Fescue (Festuca arundinacea) Cultivars in Mediterranean Ecology. Ege University, MSc in Field Crops, İzmir.

[15] Anonymous. (2002). International Union for the Protection of New Varieties of Plants (UPOV) Guidelines for the Conduct of Test for Distinctness, Homogeneity any Stability.

[16] Anonymous. (2005). United States Department of Agriculture (USDA), Agricultural Research Service, National Plant Germplasm System, National Turfgrass Evaluation Program (NTEP)(USA). 